\title{
Pemberdayaan Remaja Panti Asuhan Putri Muhammadiyah Purwokerto Tentang Kosmetik Aman dan Halal Menggunakan Metode Game Teaching
}

\author{
Much Ilham Novalisa Aji Wibowo ${ }^{1}$, Githa Fungie Galistiani² \\ 1,2 Universitas Muhammadiyah Purwokerto
}

\begin{tabular}{|c|c|}
\hline ARTICLE INFO & ABSTRACT \\
\hline $\begin{array}{l}\text { Article History: } \\
\text { Received } 30.10 .2018 \\
\text { Received in revised } \\
\text { form } 07.11 .2018 \\
\text { Accepted } 03.12 .2018 \\
\text { Available online } \\
21.12 .2018\end{array}$ & $\begin{array}{l}\text { The high mortality rate of breast cancer (BC) patients in Indonesia is associated } \\
\text { with conditions of most patients come to doctor in an advanced stage of BC. This } \\
\text { is due to low BC awareness of Indonesian women. This community service } \\
\text { program (PPM) is intended to increase knowledge of adolescent women about } \\
\text { early detection of BC. This action was conducted by BC awareness workshop to } \\
114 \text { female students of Vocational High School (SMK) } 1 \text { Cijulang, Pangandaran } \\
\text { district, West Java. The profile of participants showed that } 64 \% \text { of participants are } \\
17 \text { years old and mostly from Cijulang and Cimerak sub-districts. In addition, the } \\
\text { majority of participants were not aware of BC, indicated by lack of knowledge of } \\
\text { BC signs and symptoms ( } 97 \% \text { ), and low confident of doing breast self-examination } \\
\text { (BSE) ( } 30 \% \text { ). Moreover, there were } 7 \% \text { of participants were smoking which is } \\
\text { known to be one of the major risk factors for BC. These findings point out for } \\
\text { conducting a program for increasing BC awareness among students. The program } \\
\text { was managed by mini-lecture that focuses on BC risk factors, BC early detection } \\
\text { and BSE (SADARI) using videos and simulation on a mannequin. This program } \\
\text { was expected to have an impact on their families, indirectly. Ultimately, this will } \\
\text { increase the finding of new cases of BC which will increase their life expectancy. }\end{array}$ \\
\hline & Keywords: Breast Cancer, Breast Self-Examination, Early Detection. \\
\hline
\end{tabular}

DOI: $10.30653 / 002.201832 .79$

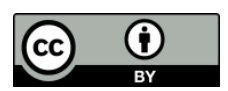

This is an open access article distributed under the terms of the Creative Commons Attribution 4.0 International License, which permits unrestricted use, distribution, and reproduction in any medium, provided the original work is properly cited. @ 2018 Much Ilham Novalisa Aji Wibowo, Githa Fungie Galistiani.

\section{PENDAHULUAN}

Indonesia memiliki pemeluk agama Islam terbanyak di dunia dengan populasi muslim yang mencapai lebih adri $80 \%$ dari jumlah total warga negaranya dan menunjukkan bahwa islam indonesia mengikuti pendekatan substantif syariat (Hosen, 2005). Angka tersebut berkorelasi dengan data ekonomi bahwa Indonesia merupakan pasar konsumen muslim yang besar. Salah satu produk yang sering digunakan oleh 
wanita muslim adalah kosmetik. Menurut MUI (2013) kosmetik dapat disebut halal bila memenuhi kriteria yaitu bahan yang digunakan tidak mengandung anjing dan babi.

Halal adalah sebuah konsep aturan prinsip agama Islam, yang digunakan untuk menyatakan bahwa sesuatu hal diijinkan atau dilarang untuk dikonsumsi oleh Muslim dengan dasar dari Al-Qur'an, hadist, atau ijtihad (kesepakatan ulama) (Luthfi \& Salehudin, 2011). Namun cukup disayangkan menurut paramitha (2016) pengetahuan remaja terhadap kosmetik berlabel halal masih kurang baik. Menurutnya hal tersebut disebabkan oleh kurangnya keingintahuan remaja terhadap kosmetik berlabel halal dan aman. Survey mandiri menyebutkan bahwa 6 dari 10 remaja putri panti asuhan muhammadiyah purwokerto yang telah menggunakan kosmetik, berpendapat bahwa tidak mengetahui aman dan halal atau tidak kosmetik yang digunakan.

Berdasarkan pemaparan di atas, maka diperlukan adanya suatu kegiatan yang dapat berdampak pada peningkatan pengetahuan melalui kegiatan pemberdayaan masyarakat. Menurut Permendagri (2007) pemberdayaan masyarakat adalah suatu strategi yang digunakan dalam pembangunan masyarakat sebagai upaya untuk mewujudkan kemampuan dan kemandirian dalam kehidupan bermasyarakat. Panti Asuhan Putri Muhammadiyah 1 Purwokerto menjadi salah satu panti asuhan khusus putri di Purwokerto dengan kategori jumlah penghuni yaitu remaja pertengahan yang sedang mulai belajar berhias. Pemberian kegiatan pemberdayaan remaja putri tentang kosmetik halal diharapkan dapat mengedukasi remaja putri tentang keamanan dan kandungan tidak halal pada kosmetik dan para remaja putri ini juga diharapkan dapat lebih bijak dan mandiri dalam memilih kosmetik yang akan digunakan.

\section{METODE PELAKSANAAN}

Berdasarkan permasalahan yang dihadapi oleh mitra dan manfaat yang didapatkan, maka kegiatan yang sesuai untuk mitra adalah penyuluhan kosmetik halal dengan metode ceramah dan game teaching. Intervensi yang diberikan melalui program Ipteks bagi Masyarakat ini bertujuan untuk memberdayakan remaja putri dengan cara meningkatkan pengetahuan dan kemandirian dalam memilih kosmetik aman dan halal bagi remaja putri di panti asuhan Muhammadiyah Purwokerto. Langkah-langkah metode Game teaching merujuk pada panduan dari Komalasari (2010).

Pengukuran pengetahuan diukur secara sederhana berdasarkan teori Arikunto (2006) menggunakan pretest dan posttest. Kuesioner pre dan posttest disusun berdasarkan teori aspek pengetahuan menurut Notoadmodjo (2007). Pengukuran pertama dilakukan pada bulan Juli 2018, penyuluhan dan pengukuran ke-2 dilakukan bulan Agustus 2018 setelah kegiatan selesai. Pengukuran pengetahuan dilakukan dengan penilaian jawaban benar pada setiap butir soal. Penilaian dilakukan dengan cara membandingkan jumlah skor jawaban dengan skor yang diharapkan (tertinggi) kemudian dikalikan $100 \%$ dan hasilnya berupa prosentase nilai pada tiap butir soal, sehingga dapat dikategorikan sesuai dengan kategori tingkat pengetahuan (Baik, Cukup dan Kurang) (Arikunto, 2010). Pretest dilaksanakan.

\section{HASIL DAN PEMBAHASAN}

Pada tahap awal pelaksanaan program dilaksanakan kegiatan berupa perancangan kerangka materi penyuluhan yang akan disampaikan. Pembuatan kerangka materi mengacu pada berbagai sumber dengan sumber utama adalah LPPOM MUI (2013) 
(Lembaga Pengkajian Pangan, Obat-obatan dan Kosmetik Majelis Ulama Indonesia). Perancangan ini dilaksanakan pada akhir bulan Juni 2018 dan pertengahan Juli 2018 yang juga melibatkan peran serta aktif mitra program pengabdian kepada masyarakat untuk membuat skala prioritas program yang dilaksanakan. Persiapan tutor dan fasilitator ini meliputi: pembuatan media power point yang menarik, mencetak materi Kosmetik Halal serta persiapan peralatan game teaching. Persiapan modul pedoman identifikasi kosmetik halal dipersiapkan lebih awal sehingga saat mendekati waktu yang ditentukan tim pelaksana melakukan finalisasi dan pencetakan modul tersebut. Persiapan selanjutnya adalah tempat yang representatif dilaksanakannya kegiatan ini yaitu di ruang pertemuan panti asuhan sehingga dapat membantu keberhasilan program ini. Pengukuran pretest dan posttest dimaksudkan agar dapat mengetahui ada atau tidaknya peningkatan pengetahuan dari mitra setelah dilakukan kegiatan. Apresiasi juga disampaikan oleh mitra yaitu dengan adanya kegiatan ini maka mitra menjadi lebih waspada terhadap kosmetik yang digunakan apakah sudah berlabel halal dan aman atau tidak. Kegiatan pemberian materi dapat dilihat pada Gambar 1.

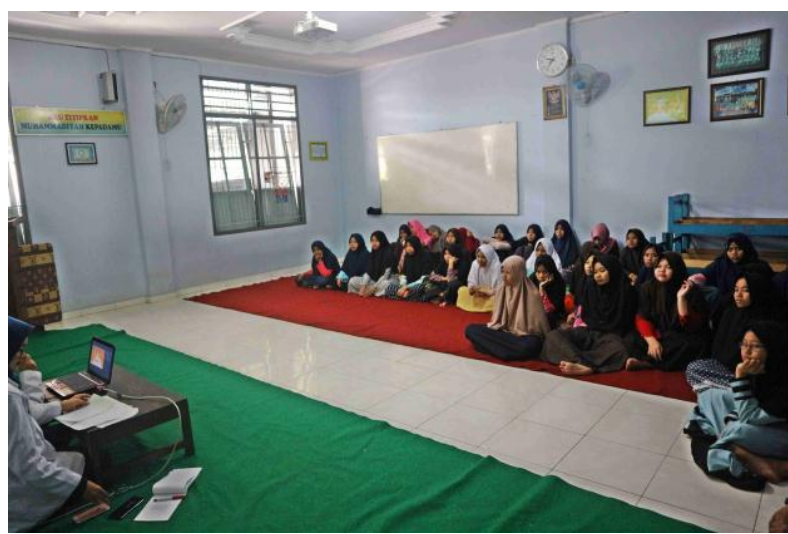

Gambar 1. Pemateri memberikan Edukasi kepada Remaja Panti Asuhan Muhammadiyah Purwokerto

Materi yang disampaikan kepada mitra dapat diterima mitra dengan baik ditandai dengan pelaksanaan game teaching yang interaktif antara penulis dan mitra serta interaksi tanya jawab dengan pemateri. Interaksi pemateri dan mitra dapat dilihat pada Gambar 2.

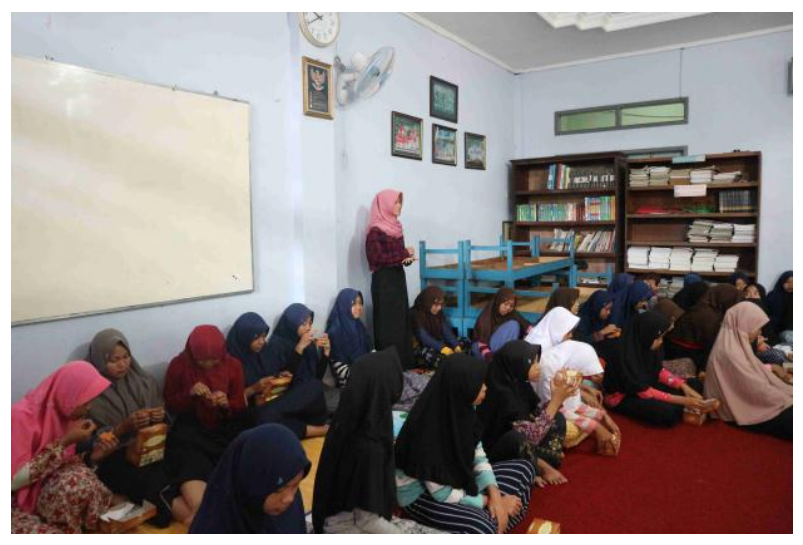

Gambar 2. Proses Interaksi Tanya Jawab Peserta

Pertanyaan yang disampaikan mayoritas langsung bertanya apakah "menyebut merk" sudah aman dan halal.. untuk menjawab pertanyaan tersebut pemateri 
menjelaskan dan mempraktekan langsung cara identifikasi bahan yang tertulis pada kemasan dan pada nomor registrasi BPOM dapat dicek melalui website BPOM. Proses game teaching dilakukan setelah sesi tanya jawab selesai. Interaksi game teaching dapat dilihat pada Gambar 3.

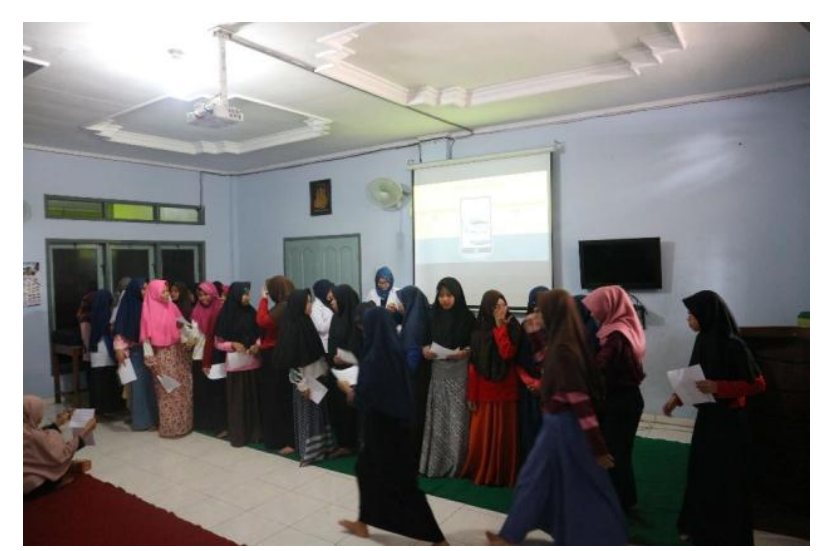

Gambar 3. Game Teaching Peserta Penyuluhan dan Posttest Pengetahuan

Pembelajaran secara game teaching termasuk dalam kategori teknik pembelajaran berkelompok (Cooperative Learning), menurut Sanjaya (2011) belajar kelompok dilakukan secara beregu. Sekelompok peserta bisa dalam skala besar atau kecil diberikan materi oleh orang guru. Teknik game teaching juga dapat dilakukan dengan sistem pengelompokan/tim kecil, yaitu antara empat sampai enam orang. Dalam kegiatan ini dibentuk kelompok kecil, setiap peserta atau penerima materi mendapatkan sebuah kartu dan memikirkan jawaban yang cocok pada setiap pertanyaan. Peserta tersebut mencari pasangan yang mempunyai kartu yang cocok dengan kartunya (soal jawabannya). Slavin dalam Sanjaya (2011) mengemukakan bahwa ada 2 alasan pentingnya pembelajaran kelompok. Pertama pembelajaran kooperatif bisa meningkatkan prestasi belajar peserta sekaligus dapat meningkatkan kemampuan hubungan sosial dan meningkatkan harga diri. Kedua pembelajaran kooperatif dapat merealisasikan kebutuhan peserta dalam belajar berpikir, memecahkan masalah, dan mengintegrasikan pengetahuan dengan keterampilannya. Pengukuran ada atau tidak peningkatan pengetahuan pada kegiatan ini dilakukan dengan pengukuran tingkat pengetahuan peserta.

\section{Analisis Pengetahuan Peserta IbM Kosmetik Halal}

\section{Karakteristik Responden}

Responden pada pengukuran adalah semua peserta dalam kegiatan IbM Kosmetik Halal di panti asuhan putri Muhammadiyah Purwokerto. Kuesioner disusun sebanyak 20 butir pertanyaan yang memenuhi 3 aspek pengetahuan yaitu mengetahui, memahami dan mengaplikasikan. Kuisioner ini diberikan kepada 37 peserta sebelum dilakukan kegiatan penyuluhan dan kembali diukur setelah dilakukan penyuluhan. Karakteristik peserta kegiatan pemberdayaan remaja putri panti asuhan Muhammadiyah Purwokerto bisa dilihat pada Tabel 1. 
Tabel 1. Karakteristik Responden Berdasarkan Usia

\begin{tabular}{llll}
\hline Keterangan & Kategori & $\Sigma$ & $\%$ \\
\hline Masa remaja awal & 12-14 tahun & 8 & $21,6 \%$ \\
Masa remaja pertengahan & 15-18 tahun & 27 & $72,9 \%$ \\
Masa remaja akhir & 19-21 tahun & 2 & $5,4 \%$ \\
\hline
\end{tabular}

Menurut Notoatmodjo (2010) salah satu faktor yang berpengaruh dalam pengisian kuisioner adalah faktor usia. Faktor tersebut akan berpengaruh terhadap cara pandang, pemikiran dan penilaian terhadap materi kuisioner yang dihubungkan dengan pengalaman yang pernah dialami. Mayoritas peserta pada kelompok remaja pertengahan yaitu rentang umur 15-18 tahun sebesar 72,9\%. Pada umur tersebut remaja sudah mulai mencari informasi atau bahkan sudah menggunakan kosmetik. Data kategori umur tersebut juga berhubungan dengan tingkat pendidikan peserta. Data tingkat pendidikan peserta dapat dilihat pada tabel 2 .

Tabel 2. Karakteristik Responden Berdasarkan Tingkat Pendidikan

\begin{tabular}{lcc}
\hline \multicolumn{1}{c}{ Tingkat pendidikan } & Jumlah & $\%$ \\
\hline SMP & 10 & $27 \%$ \\
SMK/SMA/ Setingkat & 25 & $67,5 \%$ \\
D3 & 2 & $5,4 \%$
\end{tabular}

Semakin tinggi tingkat pendidikan maka akan semakin banyak hal dan pengalaman yang sudah dilalui, sehingga akan mempermudah dalam memahami untuk pengisian kuesioner pengukuran pengetahuan (Notoadmodjo, 2010). Mayoritas kategori pendidikan peserta pada tingkatan SMK/SMA/Setingkat. Data ini sesuai dengan mayoritas tingkatan umur peserta. Dengan tingkat penddikan tersebut diharapakan tidak ada kesulitan dalam memahami pertanyaan kuesioner. Penilaian kuesioner dilakukan dengan cara membandingkan jumlah skor jawaban dengan skor yang diharapkan (tertinggi) kemudian dikalikan $100 \%$ dan hasilnya berupa prosentase.

Hasil pretest pengukuran pengetahuan dapat dilihat pada tabel 3. Berdasarkan hasil pengukuran persentase jawaban benar pada tiap pertanyaan terdapat hanya 2 butir pertanyaan dengan rentang kategori pengetahuan cukup (56\%-75\%). Pertanyaan lain dalam pengukuran sebelum dilakukan penyuluhan dalam rentang kategori pengetahuan kurang $(<56 \%)$. Mayoritas peserta tidak dapat menjawab pertanyaan kuesioner kosmetik halal dengan baik, hal ini menunjukan bahwa mayoritas peserta belum mengerti bagaimana kosmetik halal sekaligus aman.

Pengukuran posttest tingkat pengetahuan dapat dilihat pada Tabel 4. Terdapat 15 pertanyaan yang dapat dijawab dengan rentang pengetahuan cukup (56\%-75\%) dari pada saat pretest. Hal ini menunjukan mayoritas peserta dapat menjawab dengan baik pertanyaan kuesioner pengukuran pengetahuan. Adanya peningkatan terhadap pengetahuan peserta tentang produk kosmetik halal dan aman ini tidak terlepas dari peran metode belajar secara berkelompok seperti game teaching. Perhitungan tingkat pengetahuan pretest dapat dilihat pada Tabel 3. 
Tabel 3. Tingkat pengetahuan peserta (Pretest)

\begin{tabular}{|c|c|c|}
\hline No & Pertanyaan & \% jawaban benar \\
\hline 1. & $\begin{array}{l}\text { Kosmetik adalah bahan atau sediaan yang dimaksudkan untuk } \\
\text { digunakan pada bagian luar tubuh manusia }\end{array}$ & $34,2 \%$ \\
\hline 2. & $\begin{array}{l}\text { Peredaran kosmetik tidak wajib memenuhi kriteria keamanan menurut } \\
\text { BPOM dan memiliki ijin edar. }\end{array}$ & $74,7 \%$ \\
\hline 3. & Kode ijin edar BPOM untuk produk kosmetik adalah CA, NA dan CL. & $34,3 \%$ \\
\hline 4. & Semua kosmetik yang sudah ada kode nomor PIRT adalah aman & $29,5 \%$ \\
\hline 5. & $\begin{array}{l}\text { Ketentuan tentang kosmetika harus halal dan bebas dari najis telah } \\
\text { ditetapkan dalam Undang-undang tentang Jaminan Produk Halal. }\end{array}$ & $78,7 \%$ \\
\hline 6. & $\begin{array}{l}\text { Kosmetik adalah bahan atau campuran bahan untuk digosokkan, } \\
\text { dilekatkan, dituangkan, dipercikkan atau disemprotkan, dimasukkan, } \\
\text { dipergunakan pada badan atau bagian badan }\end{array}$ & $56,9 \%$ \\
\hline 7. & $\begin{array}{l}\text { Bahan yang digunakan untuk membersihkan, mewangikan dan } \\
\text { mengubah penampilan pasti produk kosmetik }\end{array}$ & $37,1 \%$ \\
\hline 8. & $\begin{array}{l}\text { Tujuan menggunakan kosmetik adalah untuk membersihkan } \\
\text { memelihara, menambah daya tarik atau mengubah rupa dan termasuk } \\
\text { termasuk golongan obat }\end{array}$ & $34,1 \%$ \\
\hline 9. & $\begin{array}{l}\text { Kosmetik yang digunakan untuk bayi termasuk kategori golongan } 1 \\
\text { menurut BPOM }\end{array}$ & $50,6 \%$ \\
\hline 10. & Merkuri dan Hidroquinon adalah bahan yang bermanfaat dalam kosmetik & $20,3 \%$ \\
\hline 11. & $\begin{array}{l}\text { Penggunaan kosmetika untuk kepentingan berhias hukumnya boleh } \\
\text { dengan syarat bahan yang digunakan adalah halal dan suci. }\end{array}$ & $45,7 \%$ \\
\hline 12. & $\begin{array}{l}\text { Menurut MUI kosmetik halal terbuat dari hewan yang memiliki cakar, } \\
\text { taring, darah, dan plasenta }\end{array}$ & $59,8 \%$ \\
\hline 13. & Ada beberapa kosmetik yang dibuat dari bagian hewan babi & $34,4 \%$ \\
\hline 14. & $\begin{array}{l}\text { Kolagen dan Ekstra Plasenta adalah bahan kosmetik yang berpotensi } \\
\text { mengandung bahan babi }\end{array}$ & $20,3 \%$ \\
\hline 15. & $\begin{array}{l}\text { Cara memilih kosmetik halal adalah membaca kandungan dalam } \\
\text { kosmetik }\end{array}$ & $46,3 \%$ \\
\hline 16. & $\begin{array}{l}\text { Kolagen digunakan dalam produk pelembab yang berguna } \\
\text { mencerahkan warna kulit }\end{array}$ & $17,3 \%$ \\
\hline 17. & $\begin{array}{l}\text { Ekstrak placenta dan amnion (cairan ketuban) dari babi bermanfaat } \\
\text { untuk meremajakan kulit }\end{array}$ & $30,6 \%$ \\
\hline 18. & $\begin{array}{l}\text { Adanya label MUI dan No.Reg BPOM adalah salah satu cara untuk } \\
\text { memilih kosmetik aman dan halal }\end{array}$ & $79,4 \%$ \\
\hline 19. & Produk kuas kosmetik bertuliskan bristle berbahan bulu sapi & $24,7 \%$ \\
\hline 20. & $\begin{array}{l}\text { Bahan gliserin dari babi juga dapat digunakan untuk bahan campuran } \\
\text { sabun cuci muka, body lotion dll }\end{array}$ & $31,5 \%$ \\
\hline
\end{tabular}


Tabel 4. Tingkat pengetahuan peserta (Posttest)

\begin{tabular}{|c|c|c|}
\hline No & Pertanyaan & $\%$ jawaban benar \\
\hline 1. & $\begin{array}{l}\text { Kosmetik adalah bahan atau sediaan yang dimaksudkan untuk digunakan } \\
\text { pada bagian luar tubuh manusia }\end{array}$ & $70,1 \%$ \\
\hline 2. & $\begin{array}{l}\text { Peredaran kosmetik tidak wajib memenuhi kriteria keamanan menurut } \\
\text { BPOM dan memiliki ijin edar. }\end{array}$ & $79,2 \%$ \\
\hline 3. & Kode ijin edar BPOM untuk produk kosmetik adalah CA, NA dan CL. & $75,0 \%$ \\
\hline 4. & Semua kosmetik yang sudah ada kode nomor PIRT adalah aman & $78,2 \%$ \\
\hline 5. & $\begin{array}{l}\text { Ketentuan tentang kosmetika harus halal dan bebas dari najis telah } \\
\text { ditetapkan dalam Undang-undang tentang Jaminan Produk Halal. }\end{array}$ & $80,6 \%$ \\
\hline 6. & $\begin{array}{l}\text { Kosmetik adalah bahan atau campuran bahan untuk digosokkan, dilekatkan, } \\
\text { dituangkan, dipercikkan atau disemprotkan, dimasukkan, dipergunakan } \\
\text { pada badan atau bagian badan }\end{array}$ & $70,7 \%$ \\
\hline 7. & $\begin{array}{l}\text { Bahan yang digunakan untuk membersihkan, mewangikan dan mengubah } \\
\text { penampilan pasti produk kosmetik }\end{array}$ & $69,1 \%$ \\
\hline 8. & $\begin{array}{l}\text { Tujuan menggunakan kosmetik adalah untuk membersihkan memelihara, } \\
\text { menambah daya tarik atau mengubah rupa dan termasuk termasuk } \\
\text { golongan obat }\end{array}$ & $74,1 \%$ \\
\hline 9. & $\begin{array}{l}\text { Kosmetik yang digunakan untuk bayi termasuk kategori golongan } 1 \text { menurut } \\
\text { BPOM }\end{array}$ & $70,6 \%$ \\
\hline 10. & Merkuri dan Hidroquinon adalah bahan yang bermanfaat dalam kosmetik & $70,8 \%$ \\
\hline 11. & $\begin{array}{l}\text { Penggunaan kosmetika untuk kepentingan berhias hukumnya boleh dengan } \\
\text { syarat bahan yang digunakan adalah halal dan suci. }\end{array}$ & $65,7 \%$ \\
\hline 12. & $\begin{array}{l}\text { Menurut MUI kosmetik halal terbuat dari hewan yang memiliki cakar, taring, } \\
\text { darah, dan plasenta }\end{array}$ & $64,8 \%$ \\
\hline 13. & Ada beberapa kosmetik yang dibuat dari bagian hewan babi & $74,4 \%$ \\
\hline 14. & $\begin{array}{l}\text { Kolagen dan Ekstra Plasenta adalah bahan kosmetik yang berpotensi } \\
\text { mengandung bahan babi }\end{array}$ & $60,7 \%$ \\
\hline 15. & Cara memilih kosmetik halal adalah membaca kandungan dalam kosmetik & $76,5 \%$ \\
\hline 16. & $\begin{array}{l}\text { Kolagen digunakan dalam produk pelembab yang berguna mencerahkan } \\
\text { warna kulit }\end{array}$ & $77,3 \%$ \\
\hline 17. & $\begin{array}{l}\text { Ekstrak placenta dan amnion (cairan ketuban) dari babi bermanfaat untuk } \\
\text { meremajakan kulit }\end{array}$ & $60,3 \%$ \\
\hline 18. & $\begin{array}{l}\text { Adanya label MUI dan No.Reg BPOM adalah salah satu cara untuk memilih } \\
\text { kosmetik aman dan halal }\end{array}$ & $69,4 \%$ \\
\hline 19. & Produk kuas kosmetik bertuliskan bristle berbahan bulu sapi & $74,4 \%$ \\
\hline 20. & $\begin{array}{l}\text { Bahan gliserin dari babi juga dapat digunakan untuk bahan campuran sabun } \\
\text { cuci muka, body lotion dll }\end{array}$ & $61,5 \%$ \\
\hline
\end{tabular}

\section{SIMPULAN}

Pemahaman para remaja pada materi kosmetik aman dan halal ini dicapai dengan dilakukannya game teaching yang menggunakan materi tentang kosmetik aman dan halal serta melibatkan setiap perserta. Terdapat peningkatan kategori pengetahuan sebelum kegiatan adalah kurang $(\leq 56 \%)$ dan setelah kegiatan adalah cukup (56\%-75\%), sehingga para remaja putri dapat berdaya untuk mengambil tindakan pencegahan dan kewaspadaan yang perlu dilakukan saat memilih kosmetik. 


\section{REFERENSI}

Arikunto, S. (2006). Prosedur penelitian suatu pendekatan praktek. Jakarta: Rineka Cipta.

Hosen, N. (2005). Religion and the Indonesian constitution: a recent debate. Journal of Southeast Asian Studies, 36(3), 419-440.

Komalasari, K. (2010). Pembelajaran kontekstual konsep dan aplikasi. Jakarta: Refika Aditama.

Luthfi, B. A., \& Salehudin, I. (2011). Marketing impact of halal labeling toward Indonesian Muslim consumer's behavioral intention based on Ajzen's Planned Behavior Theory: Policy capturing studies on five different product categories. Queensland: The University of Queensland, Australia.

MUI. (2013). Fatwa MUI nomor 26 tahun 2013 tentang standar kehalalan produk kosmetika dan penggunaannya. Jakarta: Majelis Ulama Indonesia.

Notoatmodjo, S. (2010). Metodologi penelitian kesehatan. Jakarta: Rineka Cipta

Paramita., G. P. (2016). Faktor-faktor yang mempengaruhi mahasiswa mengonsumsi kosmetik berlabel halal. Bogor: Departemen Ilmu Ekonomi, Institut Pertanian Bogor.

Permendagri RI. (2017). Peraturan menteri dalam negeri 7 Tahun 2007 tentang kader pemberdayaan masyarakat. Bandung: Fokus Media.

Sanjaya, W. (2011). Strategi pembelajaran berorientasi standar proses pendidikan. Jakarta: Kencana. 